\title{
The Impact of Repeated Death Conference Participation on Nurses' Terminal Care and Nursing in Death Conference Using the Death Conference Nursing Self-Assessment Sheet
}

\author{
Yuko Harding1,2*, Yoshiko Ishibashi' ${ }^{3}$, Mikiko Mori³, Masako Yano², Michiyo Ando ${ }^{4}$ \\ ${ }^{1}$ Faculty of Nursing, Chukyo Gakuin University, Mizunami, Japan \\ ${ }^{2}$ Faculty of Nursing, St. Mary's College, Kurume, Japan \\ ${ }^{3}$ Department of Nursing, St. Mary's Hospital, Kurume, Japan \\ ${ }^{4}$ Faculty of Nursing, Daiichi University of Pharmacy, Kurume, Japan \\ Email: *yukohardinaha@yahoo.co.jp
}

How to cite this paper: Harding, Y., Ishibashi, Y., Mori, M., Yano, M. and Ando, M. (2020) The Impact of Repeated Death Conference Participation on Nurses' Terminal Care and Nursing in Death Conference Using the Death Conference Nursing Self-Assessment Sheet. Open Journal of Nursing, 10, 903-917.

https://doi.org/10.4236/ojn.2020.109062

Received: May 1, 2020

Accepted: September 21, 2020

Published: September 24, 2020

Copyright $\odot 2020$ by author(s) and Scientific Research Publishing Inc. This work is licensed under the Creative Commons Attribution-NonCommercial International License (CC BY-NC 4.0). http://creativecommons.org/licenses/by-nc/4.0/ (c) (i) \$ Open Access

\begin{abstract}
Background: Increasing the number of DC (Death Conference) experiences, nurses are expected to improve the quality of nurses' terminal care and developing nursing minds. Therefore, there is a need for further evidence on the impact of repeated DC experiences on nurses' terminal care. Aim: This study aims to clarify the impact of repeated DC experiences on nurses' terminal care and nursing in DC using the prepared Death Conference Nursing Self-Assessment Sheet. Method: The study is approved by the Ethics Review Board of St. Mary's College, Chukyo Gakuin University, and the hospital where the survey was conducted. This study was an observational and cross-sectional study using an anonymous, self-completed questionnaire composed of the newly created Death Conference Nursing Self-Assessment Sheet. Its evaluation items in the Death Conference Nursing Self-Assessment sheet consist of four categories (Cooperation, Future direction of nursing, Specific measures for nursing, and Feeling of the nurse) and 14 questions. The questionnaires were conducted on 144 nurses in the ER, ICU, and Palliative Care Ward (Hospice Ward) in a general hospital in Japan. For analysis, JMP ver.14.2 was used to perform Fisher's exact test, Wilcoxon/Mann Whitney test, univariate, and multivariate logistic regression analysis. Results. Thirty-four participants (23.6\%) who answered the number of DC experiences were included in the final analysis. Seventeen nurses had DC experiences, and 17 had no experience. There were significant differences in all of the above categories impacting nurses' terminal care and nursing in DC. Conclusion: Repeated DC affected nurses' terminal care and nursing in DC
\end{abstract}


using the Death Conference Nursing Self-Assessment Sheet. In the future, verification of the reliability, validity of the questionnaire, and more evidence of the way of terminal concerns by raising the quality of DC for developing nursing minds will be needed.

\section{Keywords}

Death Conference (DC), Terminal Care, Self-Assessment, Nurses

\section{Introduction}

According to a report by the Ministry of Health, Labor and Welfare, the number of deaths in Japan in 2017 was 1,340,397, and the places of death were 978,260 (73\%) in hospitals, 177,473 (13.2\%) in homes, 99,910 (7.5\%) in retirement homes, 33,105 (2.5\%) in nursing homes for the elderly, and 24,144 (1.8\%) in clinics [1]. In end-of-life care, it is desirable for nurses to understand the diversity of patient values and to respect patient wills and rights. In especially ER, HCU, and Palliative Care Ward of hospitals, nurses are often involved in terminal care on a daily basis. In the daily clinical setting, patients are required to make various decisions, and nurses' support for them requires consensus in teams. Team medical care in terminal care requires the direction of improving the professionalism of each medical staff, increasing the role of each medical staff, and promoting cooperation and complementation of medical staff. Therefore, holding DC before and after terminal care is important.

Terminal care is defined as the care of terminally ill patients, such as those with terminal cancer, in which death is unavoidable, and also as the end-of-life care in emergency and intensive care, that is, when acutely ill patients treated in an intensive care unit are judged to be unlikely to be saved even after appropriate treatment is performed [2] [3] [4] [5]. Death Conference (DC) is a place where the physicians and nurses who are facing the patient's death look back on the care of the deceased patient to improve the quality of care in the future [5]-[10]. It should also include a review of nurses' terminal care of deceased patients and a case conference of patients and their families with medical staff in their department.

Participation in DC is essential for improving the quality of nurses' terminal care and fostering nursing minds. However, there are only a few studies in Japan that clarify quantitatively how nurses' participation in DC is related to the current state of terminal care. Hence, a self-assessment sheet for nursing, including the concept of the significance of DC, is necessary to reflect on daily end-of-life care, including the acute phase, and to enhance the content of DC and death education. Then, at first, we conducted a literature review in previous research to clarify the significance of DC. It explained that improving the quality of DC could lead to the improvement of the quality of patient care and the effect of ca- 
tharsis for nurses. The significance of DC showed "Refraction," "Cooperation," "Directionality of nursing," "Caring for patient," "Caring for family," "Specific methods of nursing," and "Feelings of the nurses" [11].

Next step, for clarifying the relationship between DC experiences and the current situation of terminal care for nurses who have experienced, is the newly developed Terminal Care and Death conference Nursing Self-Assessment Sheet. In our recent study (Open Journal of Nursing, 2020, vol. 10, issue 4 [5]), the result of an anonymous, self-completed questionnaire composed of the Terminal Care Nursing Self-Assessment Sheet that was conducted for 144 nurses in the ER, ICU, and Palliative Care Ward (Hospice Ward) in a general hospital in Japan, was revealed. Its evaluation of the items in the Terminal Care Nursing Self-Assessment Sheet consists of six categories (Reflection, Cooperation, Response to patients, Response to patients' family, Specific measures for nursing, and Feelings of the nurse) and 14 questions. It was shown that DC impacted on nurse's terminal care of Reflection, Cooperation, Response to patients, Response to patients' family, and Feelings of the nurse. DC that looks back on terminal care has significance as an opportunity to consider the way of terminal concerns and direction of future care [5].

Under the hypothesis where the number of DC participation will increase, nurses are expected to improve the quality of nurses' terminal care and developing nursing minds. Therefore, there was a need for further evidence on the impact of repeated DC participation on the nurses' terminal care. Hence, continuing from our previous study, this study aims to clarify the impact of repeated DC participation on nurses' terminal care and nursing in DC using the prepared Death Conference Nursing Self-Assessment Sheet.

\section{Methods}

\subsection{Participants}

The participants in this study included those in our previous studies (refer to Open Journal of Nursing, 2020, vol 10, issue 4 [5]). The following participant's information is quoted from this issue. Eligible participants were nurses who are considered to have experienced terminal care in a general hospital that has an ER, HCU, and Palliative Care Ward (Hospice Ward) in Japan. In all, we recruited 144 participants who work in an ER, HCU, and Palliative Care Ward, and who worked in May 2018. Participants excluded from the study for the following reasons: those who were not assigned to the HCU, ER, or Palliative Care Ward for more than two months.

\subsection{Procedure}

This study was an observational and cross-sectional study using an anonymous, self-completed questionnaire composed of the newly created Death Conference Nursing Self-Assessment Sheet. The method shown below is consistent with our previous research process (refer to Open Journal of Nursing, 2020, vol 10, issue 4 
[5]). The following procedure's information is quoted from this issue. The difference from the previous study is that the result is from analysis by using the Death Conference Nursing Self-Assessment Sheet.

This study was approved by the Ethics Review Board of St. Mary's College, Chukyo Gakuin University, and the hospital where surveys were completed. The study was conducted following the Declaration of Helsinki. We distributed consent documents with the anonymous, self-completed questionnaire before the survey to all participants through the head nurse from the nursing department and asked them to fill out the questionnaire as having their consent by answering freely. The consent form stated that there would be no disadvantage, even if they did not participate in the research. The survey had a response time of 10 to 15 minutes. It was placed in an envelope, sealed, and collected by collaborators using a two-week retention method. All participants underwent an anonymous, self-completed survey composed of the Terminal Care and Death conference Nursing Self-Assessment Sheet. The participant characteristics were gender, affiliation, clinical experience, age, academic background, number of postmortem experiences, and with or without and the number of DC experiences [5]. The evaluation items in the Death Conference Nursing Self-Assessment sheet consist of four categories (Cooperation, Future direction of nursing, Specific measures for nursing, and Feeling of the nurse) and 14 questions.

A Death Conference Nursing Self-Assessment Sheet was created using a 5 -step Likert scale of 1 to 5 for all items. In the beginning they are asked, "How often do you think about your nursing at the current terminal care and death conference, please circle the closest numbers respectively?" For this, the following steps were set. Here were scoring and answers for questions of all 14 items, "1) I never think about it, 2) I rarely think about it, 3) I sometimes think about it, 4) I often think about it, 5) I always think about it."

Those categories and subjects are including the concept of the significance of DC (Open Journal of Nursing, 2019, 9, p. 527) [11] that was revealed in previous literature reviews [6] [9] [10] [12] [13] [14] [15] [16], and incorporated as a conceptual framework (Table 1). Three collaborators in previous studies reviewed the category of the significance of DC. This time, to ensure content validity, the 14 assessment items were initially considered and prepared by two co-authors of university teachers with clinical experience in terminal care as nurses. Next, we obtained advice from another co-author, a college faculty member conducting terminal care research, and two other co-authors, chief nurse managers who are in charge of the terminal care ward. The translation from Japanese to English and back of the 14 items in the Death Conference Nursing Self-Assessment Sheet was con-firmed by two bilingual native adults in English and Japanese, and a request, was also sent to an English proofreading company. They also verified the consistency of these 14 items with four categories and the meaning of DC. Participants' characteristics question items are first identified by collaborators and then advised by the nursing department of the institution surveyed without the use of individual identification. 
Table 1. Items of terminal care and death conference nursing self-assessment sheet derived from literature reviews.

\begin{tabular}{|c|c|c|c|}
\hline Category* & Significance of $\mathrm{DC}^{*}$ & No. $^{\dagger}$ & $\begin{array}{l}\text { Items of Terminal Care and Death } \\
\text { Conference Nursing Self-Assessment Sheet }\end{array}$ \\
\hline Reflection & $\begin{array}{l}\text { Review of nursing care } \\
\text { provided by self-reflection }\end{array}$ & $\mathrm{T} 1$ & $\begin{array}{l}\text { I have been able to look back } \\
\text { on the nursing I performed. }\end{array}$ \\
\hline \multirow[t]{3}{*}{ Cooperation } & $\begin{array}{l}\text { Collaboration with } \\
\text { other professions }\end{array}$ & $\mathrm{T} 2$ & $\begin{array}{l}\text { I am strengthening cooperation with } \\
\text { other professions about patient care. }\end{array}$ \\
\hline & Bond with patient and family & $\mathrm{T} 13$ & $\begin{array}{l}\text { I feel a renewed bond with } \\
\text { my patients and their family. }\end{array}$ \\
\hline & Team sharing and collaboration & $\mathrm{nD6}$ & $\begin{array}{l}\text { Death Conference helps me } \\
\text { improve my teamwork. }\end{array}$ \\
\hline \multirow{4}{*}{$\begin{array}{l}\text { Future } \\
\text { direction } \\
\text { of nursing }\end{array}$} & $\begin{array}{l}\text { Share the purpose } \\
\text { and direction of care }\end{array}$ & D2 & I share the purpose and direction of care. \\
\hline & $\begin{array}{l}\text { Clarification and resolution } \\
\text { of nursing problems }\end{array}$ & D3 & $\begin{array}{l}\text { I clarify nursing problems } \\
\text { and get solutions. }\end{array}$ \\
\hline & $\begin{array}{l}\text { Proposal to connect } \\
\text { the solution to the next }\end{array}$ & D5 & $\begin{array}{l}\text { I have a proposal to connect the } \\
\text { solutions obtained for the next time. }\end{array}$ \\
\hline & Sharing of values & D7 & $\begin{array}{l}\text { I share values with people } \\
\text { who have the same thoughts. }\end{array}$ \\
\hline \multirow[t]{3}{*}{$\begin{array}{l}\text { Response } \\
\text { to patients }\end{array}$} & $\begin{array}{l}\text { Response to unrelieved mental } \\
\text { and physical pain in a patient }\end{array}$ & T5 & $\begin{array}{l}\text { I have stress resulting from the } \\
\text { patient's inability to relieve } \\
\text { mental or physical pain. }\end{array}$ \\
\hline & $\begin{array}{l}\text { Involvement with patients } \\
\text { who have a gap in perceptions } \\
\text { of the condition }\end{array}$ & T6 & $\begin{array}{l}\text { I have stress associated with } \\
\text { patients who have a different } \\
\text { perception of their conditions. }\end{array}$ \\
\hline & $\begin{array}{l}\text { The act of responding to a } \\
\text { patient's emotional expression } \\
\text { and questions about } \\
\text { patient's remaining life }\end{array}$ & $\begin{array}{l}\text { T7 } \\
\text { T8 }\end{array}$ & $\begin{array}{l}\text { I have stress on patients' emotional } \\
\text { expression. } \\
\text { I am stressed out from responding } \\
\text { to questions from patients about } \\
\text { life expectancy. }\end{array}$ \\
\hline \multirow{3}{*}{$\begin{array}{l}\text { Response to } \\
\text { patients' } \\
\text { family }\end{array}$} & $\begin{array}{l}\text { Respect for } \\
\text { family-to-patient wishes }\end{array}$ & T3 & $\begin{array}{l}\text { I respect the wishes of patients' family } \\
\text { members toward patients. }\end{array}$ \\
\hline & $\begin{array}{l}\text { Dealing with family members } \\
\text { of patients who seems to have } \\
\text { difficulty getting involved }\end{array}$ & T9 & $\begin{array}{l}\text { I am stressed out by the family of patients } \\
\text { who are considered difficult to care for. }\end{array}$ \\
\hline & $\begin{array}{l}\text { Anxiety and concern about the } \\
\text { family's treatment of patients }\end{array}$ & $\mathrm{T} 12$ & $\begin{array}{l}\text { I am anxious and worried about the } \\
\text { treatment of patients by their families. }\end{array}$ \\
\hline \multirow[t]{3}{*}{$\begin{array}{l}\text { Specific } \\
\text { measures } \\
\text { for nursing }\end{array}$} & $\begin{array}{l}\text { Procedures for postmortem } \\
\text { treatment and technique } \\
\text { concerns }\end{array}$ & nT10 & $\begin{array}{l}\text { I have misgivings about procedures } \\
\text { and skills for postmortem treatment. }\end{array}$ \\
\hline & $\begin{array}{l}\text { Learning patient care } \\
\text { at the end of life }\end{array}$ & D1 & $\begin{array}{l}\text { I feel death conference is an opportunity } \\
\text { to learn about end-of-life patient care. }\end{array}$ \\
\hline & $\begin{array}{l}\text { Understanding the will of } \\
\text { patients and their families } \\
\text { and reviewing care }\end{array}$ & $\mathrm{D} 4$ & $\begin{array}{l}\text { I understand patients and their family's } \\
\text { intentions and reflect on their care. }\end{array}$ \\
\hline $\begin{array}{l}\text { Feeling of } \\
\text { the nurse }\end{array}$ & $\begin{array}{l}\text { Thoughts of nurses who } \\
\text { support the decision-making } \\
\text { of terminal cancer patients }\end{array}$ & $\mathrm{T} 4$ & $\begin{array}{l}\text { I support the decision-making of } \\
\text { dying patients and their families. }\end{array}$ \\
\hline
\end{tabular}




\section{Continued}

\begin{tabular}{|c|c|c|}
\hline $\begin{array}{l}\text { Awareness of the emotional } \\
\text { reaction to a dying patient }\end{array}$ & T11 & $\begin{array}{l}\text { I have emotional reactions } \\
\text { towards dying patients. }\end{array}$ \\
\hline $\begin{array}{l}\text { Satisfaction with } \\
\text { satisfying patients' wishes }\end{array}$ & T14 & $\begin{array}{l}\text { I have a sense of satisfaction in fulfilling } \\
\text { the wishes of the patients, such as the } \\
\text { patients spending time with their families. }\end{array}$ \\
\hline $\begin{array}{l}\text { Stability of mind } \\
\text { through talking }\end{array}$ & D8 & $\begin{array}{l}\text { Talking at death conference } \\
\text { will calm my mind. }\end{array}$ \\
\hline $\begin{array}{l}\text { Be rebuked or accused } \\
\text { of being penitentiary }\end{array}$ & D9 & $\begin{array}{l}\text { I am always remorseful and sometimes } \\
\text { denied and accused at death conference. }\end{array}$ \\
\hline $\begin{array}{l}\text { Growing interest } \\
\text { in palliative care }\end{array}$ & D10 & $\begin{array}{l}\text { I have an increased interest of } \\
\text { palliative care after death conference. }\end{array}$ \\
\hline $\begin{array}{l}\text { Improvement in the } \\
\text { quality of care }\end{array}$ & D11 & $\begin{array}{l}\text { I can improve the quality of care } \\
\text { by participating in death conference. }\end{array}$ \\
\hline $\begin{array}{l}\text { Deepen one's view } \\
\text { of end-stage patient care }\end{array}$ & D12 & $\begin{array}{l}\text { I look back at care and deepen my } \\
\text { thoughts on end-of-life } \\
\text { patient care at death conference. }\end{array}$ \\
\hline $\begin{array}{l}\text { Improvement of } \\
\text { nurses' self-efficacy }\end{array}$ & D13 & $\begin{array}{l}\text { I can increase my self-efficacy } \\
\text { at death conference. }\end{array}$ \\
\hline Nurse's catharsis & D14 & I feel catharsis at death conference. \\
\hline
\end{tabular}

${ }^{\star}$ Open Journal of Nursing, 2019, 9, p. 527 [13]. 'No., Question No., T: Terminal Care Nursing Self-assessment items, D: Death Conference Nursing Self-assessment items. Concerning Terminal Care Nursing Self-assessment items, categories, significance of DC and those items are quoted from our previous studies (Refer to Open Journal of Nursing, 2020, vol. 10, issue 4 [5]).

\subsection{Analysis}

Data were analyzed using JMP (ver. 14.2; SAS Institute Inc., Cary, NC, U.S.). Gender, affiliation, age, academic background, and the number of postmortem experiences are expressed as observation numbers and percentages. The Fisher's exact test was used for categorical variables. The characteristics: clinical experience was evaluated by the Mann-Whitney $U$ test to investigate the difference in the groups between nurses who participate in DC: High group and Low group frequency. The results presented are in the median and IQR (interquartile range). The affiliation variable is divided into HCU and others (ER and Palliative Care Ward). The academic background variable is divided into technical college, junior college, four-year university, and others (a particular course of junior college or university, five-year school, and graduate course).

The results of the median and IQR are presented as follows. In the univariate analysis for items in the Death Conference Nursing Self-Assessment Sheet by DC experiences, which are categorized by participating in DC: High group and Low group frequency, the $P$ values from the Mann-Whitney tests are analyzed. Univariate and multivariate logistic regression analysis was used for variables in the Death Conference Nursing Self-Assessment Sheet predicting DC experiences which are categorized by participating in DC: High group and Low group frequency. In the multivariate analysis, two models are presented with the variables used for adjustment. Model 1 was adjusted for gender, age. Model 2 was adjusted 
for academic background. $P$-Values for the Whole Model Test of all variables predicting DC experience in model 1 and model 2 are by specific likelihood ratio Chi-square tests that evaluate how well the categorical model fits the data.

$P$ values $<0.05$ were considered significant. The sample size calculation used the EPI-INFO 7.0 statistical package. A sample size of at least 132 participants of the population size of 1000 nurses included public health nurses, midwives, associate nurses defined as sufficient for an $85 \%$ incidence rate with the statistical power of $80 \%$, an acceptable margin of error of $5 \%$ and a confidence level of $95 \%$.

\section{Results}

\subsection{The Process of the Enrolment and Participant Characteristics}

During the study period, 144 nurses are expected to have experienced terminal care at the department of ER, HCU, and Palliative Care Ward in a general hospital. Responses were received from all 144 participants who distributed the survey. The participants of this study are included in the analyzed 139 participants (97\%) in the final analysis of our previous studies [5]. Participants included in final analysis of this study were 34 participants (23.6\%) who answered the number of DC experiences.

Characteristics of the study participants are listed in Table 2. Each eligible nurse in the study group is classified according to DC experiences; High group $(50 \%, \mathrm{n}=17)$, or Low group $(50 \%, \mathrm{n}=17)$, and comparisons were made between the groups. Gender distribution was as follows: in the High group, there were no men and 17 women participants; in the Low group, there were a man and 16 women participants. The affiliation of nurses was nineteen participants for HCU, one for ER, and fourteen for Palliative Care Ward, fifteen (88\%) of 17 nurses in the Low group of DC experiences belong to HCU, as were twelve (71\%) in the High group. The median (interquartile range, IQR) clinical experience of all participants was 7 ( 3 - 14.8) years. The median (interquartile range) clinical experience in the High group and the No group were 20 (11.5 - 25) years and $4(3-10)$ years, respectively. Therefore, the clinical experience was much longer in the High group of DC experiences. Twelve of all participants (41\%) were age $<30$. There was a larger proportion of nurses in the Low group 12 (71\%) than in the High group Two $(12 \%)$ in the age group $<30$ years. Thirteen nurses among the entire group (38\%) had a technical college academic background, and there was a larger proportion of nurses in the High group 9 than in the Low group 4 in the technical college group. Twenty-one (62\%) nurses had experienced more than 20 postmortem treatments, none said that they had not experienced postmortem treatment. The number distribution of postmortem experiences was as follows: in the High group, 0,1 , and 16 nurses in number of postmortem experiences $1-9,10-19$, and $\geq 20$, respectively; in the Low group, 10, 2, and 5 nurses, respectively. There was, therefore, a higher proportion of the number of postmortem experiences $\geq 20$ in the High group $(P<0.001)$ (Table 2). 
Table 2. Participant characteristics.

\begin{tabular}{|c|c|c|c|}
\hline \multirow{2}{*}{ Characteristics } & \multicolumn{2}{|c|}{ DC experiences } & \multirow{2}{*}{$\begin{array}{c}P \\
\text { value }\end{array}$} \\
\hline & $\operatorname{High}(\mathrm{n}=17)$ & Low $(n=17)$ & \\
\hline Gender, no. $(\%)^{*}$ & & & 1.00 \\
\hline Men & $0(0)$ & $1(6)$ & - \\
\hline Women & $17(100)$ & $16(94)$ & - \\
\hline Affiliation, no. (\%)* & & & $<0.001$ \\
\hline $\mathrm{HCU}$ & $4(24)$ & $15(88)$ & $<0.01$ \\
\hline Others $^{\dagger} \mathrm{ER}$ & $1(6)$ & 0 & 1.0 \\
\hline Palliative Care Ward & $12(71)$ & $2(12)$ & 0.001 \\
\hline Clinical experience, Median (IQR), $\mathrm{y}^{\ddagger}$ & $20(11.5-25)$ & $4(3-10)$ & $<0.001$ \\
\hline Age group, no. (\%)* & & & $<0.01$ \\
\hline$<30$ & $2(12)$ & $12(71)$ & 0.001 \\
\hline 30-39 & $5(29)$ & $4(24)$ & 1.0 \\
\hline$\geq 40$ & $10(59)$ & $1(6)$ & 0.002 \\
\hline Academic background, no. $(\%)^{*}$ & & & 0.146 \\
\hline Technical college & $9(53)$ & $4(24)$ & 0.157 \\
\hline Junior college & $3(18)$ & $3(18)$ & 1.0 \\
\hline Four-year university & $1(6)$ & $6(35)$ & 0.085 \\
\hline Others $^{\S}$ & $4(24)$ & $4(24)$ & 1.0 \\
\hline Number of postmortem experience, chance, no $(\%)^{*}$ & & & $<0.001$ \\
\hline 0 & 0 & 0 & - \\
\hline $1-9$ & 0 & $10(59)$ & $<0.001$ \\
\hline $10-19$ & $1(6)$ & $2(12)$ & 1.00 \\
\hline$\geq 20$ & $16(94)$ & $5(29)$ & $<0.001$ \\
\hline
\end{tabular}

IQR, interquartile range. DC, Death Conference. DC experiences were categorized by participating in DC: High or Low. ${ }^{\star} P$ values are from Fisher's exact test analyzed on nonparametric comparisons between nurses who participate in DC: High group and Low group frequency. ${ }^{\dagger}$ Others included ER and Palliative Care Ward. ${ }^{\ddagger} P$ values are from the Mann-Whitney $\mathrm{U}$ test analyzed on nonparametric comparisons between nurses who participate in DC: High group and Low group frequency. ${ }^{s}$ Others included who graduated a particular course of junior college or university, five-year school, and graduate course.

No significant differences in characteristics were observed in gender or academic background.

\subsection{In the Univariate Analysis for Items in the Death Conference Nursing Self-Assessment Sheet by DC Experiences}

In the univariate analysis for items in the Death Conference Nursing Self-Assessment Sheet by DC experiences; High group and Low group frequency listed in Table 3. Nurses who had experience in DC showed significant results (Question No., Category-Items of the Death Conference Nursing Self-Assessment Sheet) on the following questions. D4. Specific measures for nursing-understanding 
Table 3. Univariate analysis for items of death conference nursing self-assessment Sheet by DC experiences.

\begin{tabular}{|c|c|c|c|c|}
\hline \multirow[b]{2}{*}{ No.* } & \multirow[b]{2}{*}{ Variables $^{\dagger}$} & \multicolumn{3}{|c|}{$\underline{\text { DC experiences }}$} \\
\hline & & $\begin{array}{l}\text { High } \\
\mathrm{n}=17\end{array}$ & $\begin{array}{c}\text { Low } \\
\mathrm{n}=17\end{array}$ & $\begin{array}{c}P \\
\text { values }^{\ddagger}\end{array}$ \\
\hline D1. & $\begin{array}{l}\text { I feel death conference are an opportunity } \\
\text { to learn about end-of-life patient care. }\end{array}$ & $4(3-4.5)$ & $4(3-4)$ & 0.267 \\
\hline D2. & I share the purpose and direction of care. & $4(3-4.5)$ & $3(2.5-4)$ & 0.074 \\
\hline D3. & I clarify nursing problems and get solutions. & $4(3-4)$ & $3(2.5-3.5)$ & 0.070 \\
\hline D4. & $\begin{array}{l}\text { I understand patients and their families' } \\
\text { intentions and reflect on their care. }\end{array}$ & $4(3-4)$ & $3(2-4)$ & 0.047 \\
\hline D5. & $\begin{array}{l}\text { I have a proposal to connect the solutions } \\
\text { obtained for the next time. }\end{array}$ & $4(3.5-4)$ & $3(2-3)$ & $<0.001$ \\
\hline D6. & $\begin{array}{l}\text { Death conference helps me improve } \\
\text { my teamwork. }\end{array}$ & $4(2-4)$ & $2(2-3)$ & 0.011 \\
\hline D7. & $\begin{array}{l}\text { I share values with people who have } \\
\text { the same thoughts. }\end{array}$ & $4(3-4)$ & $3(2-3.5)$ & 0.004 \\
\hline D8. & $\begin{array}{l}\text { Talking at death conference will } \\
\text { calm my mind. }\end{array}$ & $3(2-4)$ & $2(2-3)$ & 0.027 \\
\hline D9. & $\begin{array}{l}\text { I am always remorseful and sometimes } \\
\text { denied and accused at death conference. }\end{array}$ & $2(1-3.8)$ & $2(1-2)$ & 0.529 \\
\hline D10. & $\begin{array}{l}\text { I have an increased interest of palliative } \\
\text { care after death conference. }\end{array}$ & $4(3-4)$ & $3(2-4)$ & 0.074 \\
\hline D11. & $\begin{array}{l}\text { I can improve the quality of care by } \\
\text { participating in death conference. }\end{array}$ & $4(3-4)$ & $3(2-4)$ & 0.090 \\
\hline D12. & $\begin{array}{l}\text { I look back at care at death conference and } \\
\text { deepen my thoughts on end-of-life patient } \\
\text { care at death conference. }\end{array}$ & $4(4-4)$ & $3(2-4)$ & 0.025 \\
\hline D13 & $\begin{array}{l}\text { I can increase my self-efficacy at } \\
\text { death conference. }\end{array}$ & $4(3-4)$ & $3(2-3.5)$ & 0.019 \\
\hline D14 & I feel catharsis at death conference. & $4(2-4)$ & $3(2-3)$ & 0.089 \\
\hline
\end{tabular}

${ }^{\star}$ No., Question No., D, Items of Death Conference Nursing Self-Assessment Sheet. Data are Median (IQR; interquartile range). 'Variables, Items of Death Conference Nursing Self-Assessment Sheet. DC, Death Conference, DC experiences were categorized by participating in DC: High or Low. ${ }^{\ddagger} P$ values are from the Mann-Whitney $U$ test analyzed on nonparametric comparisons between nurses who participate in DC: High group and Low group frequency.

patients and their family's intentions and reflect on their care $(P=0.047), \mathrm{D} 5$. Future direction of nursing-having a proposal to connect the solutions obtained for the next time $(P<0.001)$, D6. Cooperation-DC helps me improve my teamwork $(P=0.011)$, D7. Future direction of nursing-sharing values with people who have the same thoughts $(P=0.004), \mathrm{D} 8$. Feeling of the nurse-talking at DC will calm my mind $(P=0.027), \mathrm{D} 12$. Feeling of the nurse-looking back at care and deepen my thoughts on end-of-life patient care at the DC $(P=$ $0.025)$, D13. Feeling of the nurse-can increase my self-efficacy at DC $(P=$ $0.019)$. 
However, items that did not show a significant relationship with DC experiences; High group and Low group frequency were as follows: D1. Specific measures for nursing-feeling DC are an opportunity to learn about end-of-life patient care $(P=0.267)$, D2. Future direction of nursing - sharing the purpose and direction of care $(P=0.074)$, D3. Future direction of nursing-clarifying nursing problems and get solutions $(P=0.070)$, D9. Feeling of the nurse-being always remorseful and sometimes denied and accused at DC $(P=0.529), \mathrm{D} 10$. Feeling of the nurse-having an increased interest of palliative care after DC ( $P$ $=0.074)$, D11. Feeling of the nurse-can improve the quality of care by participating in DC $(P=0.090)$, D14. Feeling of the nurse-feeling catharsis at DC $(P=$ 0.089) (Table 3).

\subsection{Univariate and Multivariate Logistic Regression Analysis for Items of Terminal Care Nursing Self-Assessment Sheet Predicting DC Experiences}

Univariate and multivariate logistic regression analysis for items of the Death Conference Nursing Self-Assessment Sheet predicting DC experiences; High group and Low group frequency are shown in Table 4. In univariate logistic regression analysis, all variables, the original concept, which is the significance of DC included items of the Death Conference Nursing Self-Assessment Sheet

Table 4. Univariate and multivariate logistic regression analysis for items of death conference nursing self-assessment sheet predicting DC experiences.

\begin{tabular}{|c|c|c|c|c|c|c|c|c|c|c|}
\hline \multirow[b]{2}{*}{ Variable } & \multirow[b]{2}{*}{ No. } & \multirow[b]{2}{*}{$\begin{array}{l}\text { Crude } \\
\text { OR }\end{array}$} & \multirow[b]{2}{*}{$\begin{array}{c}95 \% \\
\mathrm{Cl}\end{array}$} & \multirow[b]{2}{*}{$\begin{array}{c}P \\
\text { value }\end{array}$} & \multicolumn{3}{|c|}{ Model 1} & \multicolumn{3}{|c|}{ Model 2} \\
\hline & & & & & $\begin{array}{l}\text { Adjusted } \\
\mathrm{OR}^{*}\end{array}$ & $\begin{array}{c}95 \% \\
\mathrm{Cl}\end{array}$ & $\begin{array}{c}P \\
\text { value }\end{array}$ & $\begin{array}{c}\text { Adjusted } \\
\mathrm{OR}^{\dagger}\end{array}$ & $\begin{array}{c}95 \% \\
\mathrm{Cl}\end{array}$ & $\begin{array}{c}P \\
\text { value }\end{array}$ \\
\hline $\begin{array}{l}\text { Cooperation } \\
\text { Team sharing and collaboration }\end{array}$ & D6 & 2.54 & $\begin{array}{l}1.20 \\
5.37\end{array}$ & 0.007 & 2.47 & $\begin{array}{l}0.87 \\
7.04\end{array}$ & 0.066 & 2.41 & $\begin{array}{l}1.10 \\
5.25\end{array}$ & 0.016 \\
\hline $\begin{array}{l}\text { Future direction of nursing } \\
\text { Proposal to connect the solution to the next }\end{array}$ & D5 & 6.12 & $\begin{array}{l}1.76 \\
21.22\end{array}$ & $<0.001$ & 5.99 & $\begin{array}{l}1.32 \\
27.32\end{array}$ & 0.004 & 6.00 & $\begin{array}{l}1.59 \\
22.63\end{array}$ & 0.001 \\
\hline Sharing of values & D7 & 4.30 & $\begin{array}{l}1.45 \\
12.81\end{array}$ & 0.002 & 3.20 & $\begin{array}{l}0.82 \\
12.50\end{array}$ & 0.007 & 4.10 & $\begin{array}{l}1.26 \\
13.35\end{array}$ & 0.006 \\
\hline $\begin{array}{l}\text { Specific measures for nursing } \\
\text { Understanding the will of patients and } \\
\text { their families and reviewing care }\end{array}$ & D4 & 2.35 & $\begin{array}{l}1.00 \\
5.53\end{array}$ & 0.035 & 2.59 & $\begin{array}{l}0.79 \\
8.47\end{array}$ & 0.083 & 2.73 & $\begin{array}{l}1.02 \\
7.30\end{array}$ & 0.029 \\
\hline $\begin{array}{l}\text { Feeling of the nurse } \\
\text { Stability of mind through talking }\end{array}$ & D8 & 2.70 & $\begin{array}{l}1.14 \\
6.40\end{array}$ & 0.011 & 1.49 & $\begin{array}{l}0.51 \\
4.34\end{array}$ & 0.454 & 2.69 & $\begin{array}{l}1.00 \\
7.22\end{array}$ & 0.027 \\
\hline Deepen one's view of end-stage patient care & D12 & 2.55 & $\begin{array}{l}1.02 \\
6.34\end{array}$ & 0.028 & 2.40 & $\begin{array}{l}0.77 \\
7.49\end{array}$ & 0.106 & 2.47 & $\begin{array}{l}0.94 \\
6.54\end{array}$ & 0.049 \\
\hline Improvement of nurses' self-efficacy & D13 & 2.59 & $\begin{array}{l}1.14 \\
5.87\end{array}$ & 0.013 & 3.18 & $\begin{array}{l}0.92 \\
10.98\end{array}$ & 0.033 & 2.87 & $\begin{array}{l}1.15 \\
7.15\end{array}$ & 0.011 \\
\hline
\end{tabular}

DC, Death Conference, OR, odds ratio. CI, confidence interval. No., question no. Variable, the original concept of items of Death Conference Nursing Self-Assessment Sheet (refer Table 2). ${ }^{*}$ Adjusted for gender, age. (Model 1), ${ }^{\dagger}$ Adjusted for academic background. (Model 2). DC experiences were categorized by participating in DC: High or Low. OR reviled High/Low. $P$-Values for the Whole Model Test of all variables predicting DC experience in model 1 and model 2 are all less than 0.05 , which are by specific likelihood ratio Chi-square tests that evaluate how well the categorical model fits the data. Participation experience in Death Conference was categorized by the participation experience High or Low. 
(Refer Table 3), are shown to be independent risk factors for DC experiences as follow (Question No., Category). D6. Cooperation (OR 2.54, 95\% CI, 1.20, 5.37, $P<0.007$ ), D5. Future direction of nursing (OR 6.12, 95\% CI, 1.76, 21.22, $P<$ 0.001 ), D7. Future direction of nursing (OR 4.30, 95\% CI, 1.45, 12.81, $P=0.002$ ), D4. Specific measures for nursing (OR 2.35, 95\% CI, 1.00, 5.53, $P=0.035$ ), D8. Feeling of the nurse (OR 2.70, 95\% CI, 1.14, 6.40, $P=0.011$ ), D12. Feeling of the nurse (OR 2.55, 95\% CI, 1.02, 6.34, $P<0.028$ ), D13. Feeling of the nurse (OR $2.59,95 \% \mathrm{CI}, 1.14,5.87, P<0.013)$.

In model 1 of the multivariate logistic regression analysis adjusted for gender, age, variables; the original concept, which is the significance of DC of items of the Death Conference Nursing Self-Assessment Sheet, are shown to be independent risk factors for DC experiences. High group and Low group frequency are as follows (Question No., Category). D5. Future direction of nursing (OR 5.99, 95\% CI, 1.32, 27.32, $P=0.004$ ), D7. Future direction of nursing (OR 3.20, 95\% CI, $0.82,12.50, P=0.007$ ) and D13. Feeling of the nurse (OR 3.18, 95\% CI, 0.92, $10.98, P=0.033)$. However, in the following questions of D6, D4, D8, and D12, no significant difference was seen using model 1.

In model 2 of the multivariate logistic regression analysis was adjusted for academic background, variables; the original concept, which is the significance of DC of items of the Death Conference Nursing Self-Assessment Sheet, are shown to be independent risk factors for DC experiences. High group and Low group frequency are as follows (Question No., Category). D6. Cooperation (OR 2.41, 95\% CI, 1.10, 5.25, $P=0.016$ ), D5. Future direction of nursing (OR 6.00, 95\% CI, 1.59, 22.63, $P=0.001$ ), D7. Future direction of nursing (OR 4.10, 95\% CI, 1.26, 13.35, $P=0.006$ ), D4. Specific measures for nursing (OR 2.73, 95\% CI, $1.02,7.30, P=0.029$ ), D8. Feeling of the nurse (OR 2.69, 95\% CI, 1.00, 7.22, $P=$ 0.027), D12. Feeling of the nurse (OR 2.47, 95\% CI, 0.94, 6.54, $P=0.049$ ), D13. Feeling of the nurse (OR 2.87, 95\% CI, 1.15, 7.15, $P=0.011$ ).

\section{Discussion}

\subsection{Nurses' Terminal Care Related to DC Experiences and Nursing in the Death Conference Using the Death Conference Nursing Self-Assessment Sheet}

Under the hypothesis that increasing the number of DC participation, nurses were expected to improve the quality of nurses' terminal care and developing nursing minds. Therefore, there was a need for further evidence on the impact of repeated DC participation on nurses' terminal care. Hence, continuing from our previous study clarify [5], we analyzed that the impact of repeated DC participation on nurses' terminal care and nursing in DC using the prepared Death conference Nursing Self-Assessment Sheet. There were significant differences in four categories (Cooperation, Future direction of nursing, Specific measures for nursing, and Feeling of the nurse). The current results show that repeated DC participation concerns about the impacted on nurses' terminal care and nursing in DC. 
For the assessment items of the categories that were significant in the univariate analysis described above, a significant association with the experience of participating in DC; High group and Low group frequency was confirmed by univariate and multivariate logistic regression using adjustment factor of an academic background. The verification of the reliability and validity of the questionnaire are the challenge in the future. More evidence of the way of terminal concerns by raising the quality of DC developing nursing minds will be needed using the Terminal Care and Death Conference Nursing Self-Assessment Sheet. Moreover, research to see the relationship between items of the Terminal Care Nursing Self-Assessment Sheet and items of the Death Conference Nursing Self-Assessment Sheet will also be needed. Nurses should resolve the stress associated with terminal care by participating in DC [5], and consider how to operate DC so that nurses can grow not only in nursing but also as a whole.

\subsection{Current Status and Issues of Nurses' Terminal Care and Nursing in the Death Conference That Was Not Related to DC Experiences}

There was no significant association between the experience of participating in DC and the following category (the significance of DC) corresponding to items in the Death Conference Nursing Self-Assessment Sheet. They are the following category (the significance of DC) that Specific measures for nursing (learning patient care at the end of life), Future direction of nursing (share the purpose and direction of care, clarification and resolution of nursing problems), Feeling of the nurse (be rebuked or accused of being penitentiary, growing interest in palliative care, improvement in the quality of care and nurse's catharsis).

Concerning specific measures for nursing (learning patient care at the end of life), it is necessary to acquire knowledge and skills through training. In hospitals, it is necessary to examine the contents of nursing standards and procedures related to postmortem treatment, dealing with family members at that time, and regarding DC. Regular training needs to be held throughout the hospital or in each ward department to acquire knowledge and skills in terminal care.

About future direction of nursing (share the purpose and direction of care, clarification and resolution of nursing problems), it is necessary to have a time to hold DC regularly and to analyze the content and quality of DC to reduce the stress of nurses performing terminal care even in busy to respond to patients and their families. It is necessary to hold DC regularly, analyze the content and quality of DC using the assessment sheet used this time, and make improvements as appropriate. Nurses and health care professionals should share the development of the nursing process of patients and their families, classify and resolve problems that have arisen in dealing with patients and their families, and build evidence.

According to feeling of the nurse (be rebuked or accused of being penitentiary, growing interest in palliative care, improvement in the quality of care and nurse's catharsis), at the conference, nurses and healthcare professionals should 
never blame each other's nurses or impose their responsibilities on particular nurses, as indicated in the definition of DC. Nurses and healthcare professionals should maintain DC as a place where they can find directions for using in the next nursing, and the aim is to improve nursing. With the participation of DC, the team can support nurses to share their own problems, feel catharsis by solving them, and take a new interest in terminal care.

This study has several limitations. The generalizability may be limited because the number of participants was very small. To generalize these results, we need to add many more participants. The future task is to verify the reliability and validity of the Terminal Care and Death Conference Nursing Self-Assessment Sheet.

\section{Conclusion}

It suggests that with the increasing number of DC participation, nurses are expected to improve the quality of nurse's terminal care and developing nursing minds. The impact of repeated DC participation on nurses' terminal care and nursing in DC using the prepared Death Conference Nursing Self-Assessment Sheet was analyzed. There were significant differences in four categories (Cooperation, Future direction of nursing, Specific measures for nursing, Feeling of the nurse). The current results show that repeated DC participation concerns the impact on nurses' terminal care and nursing in DC.

\section{Conflicts of Interest}

The authors declare no conflicts of interest regarding the publication of this paper.

\section{Funding}

This research did not receive any specific grant from funding agencies in the public, commercial, or not-for-profit sectors.

\section{Authors' Contributors}

Yuko Harding: participated in the conception and design, analysis and interpretation of data, drafting the article, revising it for intellectual content, and final approval of the finished article.

Yoshiko Ishibashi: acquisition of data, final approval of the finished article. Mikiko Mori: acquisition of data, final approval of the finished article.

Masako Yano: participated in the conception and design, interpretation of data, revising it for intellectual content, final approval of the finished article.

Michiyo Ando: revising it for intellectual content, final approval of the finished article.

\section{References}

[1] Ministry of Health, Labor and Welfare (2018) Welfare Statistics Handbook. Part I, 
Population Households, Chapter II, Demographics, Number of Deaths/Composition, Location of Death, Tables 1-25.

https://www.mhlw.go.jp/toukei/youran/indexyk_1_2.html

[2] Kashiwagi, T. (2007) Life and Death (1) Medicine Various Words about End-of-Life Care. Clinic All-Round, 56, 2744-2748. https://ci.nii.ac.jp/naid/40015621486

[3] Asami, A. (2013) The Relationship between End-of-Life Care and Nurses' Awareness of End-of-Life Care in the ICU. Journal of Japan Academy of Critical Care Nursing, 9, 39-47.

https://jglobal.jst.go.jp/en/detail?JGLOBAL_ID=201302279493360590\&rel

[4] End-of-Life Nursing Practice Guide in Emergency and Intensive Care Units. http://jaen.umin.ac.jp/EOL_guide.html

[5] Harding, Y., Ishibashi, Y., Mori, M., Yano, M. and Ando, M. (2020) Relationship between Death Conference Experiences and Nurses' Terminal Care. Open Journal of Nursing, 10, 381-395. https://doi.org/10.4236/ojn.2020.104026

[6] Hirose, H. (2011) Grief Care for Family and Nurses. Igaku-Shoin Ltd., Tokyo. https://iss.ndl.go.jp/books/R100000002-I000011224361-00

[7] Hasebe, M., Taguchi, M. and Tsuge, M. (2012) Effect of Death Conferences as Seen from Changes in Nurses' Comments. Nihon Kango Gakkai Rombunshuu, Kango Sougou, 42, 218-221. https://iss.ndl.go.jp/books/R000000004-I023617204-00

[8] Naito, C., Nakai, O., Omote, S., Yabuta, Y., Hoshino, T. and Miyahata, T. (2009) The Effect of Death Conferences in Terminal Care; Evaluation of Stress Reduction Using POMS. Nihon Kango Gakkai Rombunshuu, Kango Kanri, 39, 330-332. https://jglobal.jst.go.jp/en/detail?JGLOBAL_ID=200902260488192837

[9] Hasegawa, M., Eto, A. and Yamauchi, N. (2007) Impact of Death Conferences in the Medical Team on Nurses' Self-Efficacy. Nihon Kango Gakkai Rombunshuu, Kango Sougou, 38, 49-51.

https://jglobal.jst.go.jp/en/detail?JGLOBAL_ID=200902285011484057

[10] Kobayashi, M. and Shibuya, M. (2010) Consideration of Terminal Care in Our Hospital Ward. By Introducing Death Conferences. Pre-Symptomatic Medicine and Anti Aging, 19, 143-145. https://jglobal.jst.go.jp/en/detail?JGLOBAL_ID=201002214228207333

[11] Harding, Y., Ando, M. and Yano, M. (2019) Literature Review on the Significance of Death Conferences for Nurses in Japan. Open Journal of Nursing, 9, 521-533. https://www.scirp.org/journal/paperinformation.aspx?paperid=92618 https://doi.org/10.4236/ojn.2019.95044

[12] Tanaka, H., Moriya, A. and Sakiko, K. (2014) The Thoughts of a Nurse Supporting an End-Term Cancer Patient's Decision-Making: Nursing Which Builds Close Relationships to the Patient Family Who Passes the Time of the Last Moment Is Considered. Annals of Nursing Research, Shinshu University Hospital, 42, 38-40. https://ci.nii.ac.jp/naid/40020282208

[13] Adachi, K. and Tashiro, M. (2012) Deployment of Death Conferences and Nurse's Mind. From a Survey of Nurses for the Introduction. The Japanese Psychiatric Nursing Association, 55, 550-551. https://jglobal.jst.go.jp/en/detail?JGLOBAL_ID=201202226647441608

[14] Koyama, K., Kazama, K., Nakamura, M., Aonuma, E. and Yoshikawa, K. (2012) Behavioral Change of Staff by Death Conferences in Acute Care Ward-Aiming at Improvement of Quality of Terminal Care. Nagano-Prefecture Kango Kenkyuu Gakkai Rombunshuu, 32, 79-81.

https://jglobal.jst.go.jp/en/detail?JGLOBAL_ID=201202259594399200 
[15] Ishikawa, C. and Hashizume, T. (2010) Nurse's Stress in Palliative Care Seen from Death Conferences. The Medical Journal of Akita City Hospital, 19, 1-5. https://jglobal.jst.go.jp/en/detail?JGLOBAL_ID=201002226948889952

[16] Tsuchie, K., Sasaki, M., Kumagai, N. and Ishibashi, T. (2010) Analysis of Way of Grasping Death Conferences by Nurses in Chronic Medical Ward and Consideration of Effective Progress. Nihon Kango Gakkai Rombunshuu, Kango Sougou, 40, 425-427. https://jglobal.jst.go.jp/en/detail?JGLOBAL_ID=201002206420128002 